\title{
Trap Deaths in Woodland Rodents
}

\author{
John GURNELL
}

\begin{abstract}
Gurnell J., 1982: Trap deaths in woodland rodents. Acta theriol., 27, 11: 139-147 [With 6 Tables]

Trap deaths in wood mice (Apodemus sylvaticus, Linnaeus 1758) and bank voles (Clethrionomys glareolus, Schreber 1780) have been investigated using a five year live trapping study in an oak wood in Southern England and various factors which may affect the number of trap deaths have been examined. It appears that moisture within the trap, associated with low temperatures, is a significant contributing factor towards trap mortalities, but also that stress resulting from trap confinement and the start of the breeding season may also be important.

[Dept. of Zoology, Westfield College, Univ, London, London NW3 7S'T, England.
\end{abstract}

\section{INTRODUCTION}

Trap mortalities inevitably occur in small mammal live trapping studies and in certain circumstances they could affect the observed long-term dynamics of a population. Moreover, it has been suggested that trap deaths may be used as an indicator of population stress (Platt, 1968) and that some animals may inherently be more resistant to dying in traps than others (Montgomery, 1981). This paper presents an analysis of trap deaths in wood mice and bank voles from a five year study on the dynamics of these species in an oak woodland in Southern England. The possible factors responsible for trap deaths are examined.

\section{METHODS}

Full details of the study area and trapping methods are given in Gurnell (1982). In short, 55 trapping periods, each consisting of 3 or 4 trapping nights, were carried out in a mature oak (Quercus robur) woodland in Alice Holt Forest, Surrey,-England between June 1975 and June 1980. The standard trapping procedure was to place 144 Longworth live traps two to a point on a $10 \mathrm{~m}$. spaced grid consisting of 8 rows by 9 columns, although some minor variations to this procedure were sometimes adopted (Gurnell, 1982). The traps contained hay bedding and whole oats, and oats were used as bait. The traps were set and visited early in the morning, and bait and food in the traps were replenished where necessary. A standard policy was to discontinue trapping after three nights in any trap period if cold, wet conditions persisted. At the beginning of 1978 this policy was extended to delaying the start of trapping if the weather was unfavourable. Daily weather records were collected from the Alice Holt Forest Research Institute's Meteorological Station situated some $600 \mathrm{~m}$. from the 
study area. Forest floor minimum temperatures were obtained from a max-min. thermometer placed in the leaf litter under a bramble bush in the study area. (The relative humidity figures refer to the time that the records were made at the Meteorological Station, i.e. 9.00 in the morning.). Once captured, animals were individually toe-clipped if they were unmarked, weighed, sexed, breeding condition noted, and released.

\section{RESULTS}

Over the five years of trapping 80 trap deaths occurred in wood mice, 93 in bank voles and 11 in yellow-necked mice, A. flavicollis (Melchior, 1834). The deaths in yellow-necked mice represented $4.8 \%$ of the total number of individuals of this species captured but these data are too few to be analysed in more detail.

Table 1 presents the number of deaths in wood mice and bank voles according to the following seasons of the year: winter-December to February (inclusive); spring - March to May; summer-June to August; autumn - September to November.

Table 1

Trap deaths: $\mathrm{a}=$ June 1975 to Dec. $1977, \mathrm{~b}=\mathrm{Jan} .1978$ to June $1980, \mathrm{t}=$ June 1975 to June 1980 .

\begin{tabular}{|c|c|c|c|c|c|c|c|c|c|c|c|c|}
\hline \multirow[b]{2}{*}{ Season } & \multicolumn{3}{|c|}{ No. deaths } & \multicolumn{3}{|c|}{$\begin{array}{l}\text { No. deaths } \\
\text { per trap } \\
\text { night }\left(\times 10^{3}\right)\end{array}$} & \multicolumn{3}{|c|}{$\begin{array}{l}\% \text { indivs. capt. } \\
\text { dying in traps }\end{array}$} & \multicolumn{3}{|c|}{$\begin{array}{l}\% \text { captures } \\
\text { resulting in } \\
\text { death }\end{array}$} \\
\hline & $a$ & b & $t$ & $\bar{a}$ & b & $\bar{t}$ & a & $\mathrm{b}$ & $t$ & a & b & $t$ \\
\hline \multicolumn{13}{|c|}{ Wood mice } \\
\hline Winter & 33 & 4 & 37 & 11.6 & 1.6 & 7.0 & 14.5 & 3.2 & 10.5 & 8.2 & 1.5 & 5.6 \\
\hline Sprin & 4 & 9 & 13 & 1.7 & 1.8 & 1.8 & 2.2 & 5.5 & 3.8 & 1.2 & 2.2 & 1.7 \\
\hline Summer & 1 & 0 & 1 & 0.2 & 0.0 & 0.1 & 0.4 & 0.0 & 0.3 & 0.2 & 0.0 & 0.1 \\
\hline Autumn & 27 & 2 & 29 & 5.2 & 0.6 & 3.4 & 10.1 & 1.4 & 7.1 & 4.1 & 0.7 & 3.1 \\
\hline Total & 65 & 15 & 80 & 4.4 & 1.1 & 2.8 & 7.0 & 2.9 & 5.5 & 3.2 & 1.3 & \\
\hline \multicolumn{13}{|c|}{ Bank voles } \\
\hline Winter & 15 & 7 & 22 & 5.3 & 2.9 & 4.2 & 13.2 & 7.2 & 10.4 & 8.7 & 3.9 & 6.2 \\
\hline Spring & 25 & 13 & 38 & 10.9 & 2.6 & 5.2 & 17.2 & 14.0 & 16.0 & 11.3 & 6.5 & 9.0 \\
\hline Summer & 12 & 0 & 12 & 2.6 & 0.0 & 1.7 & 5.2 & 0.0 & 4.1 & 2.8 & 0.0 & 2.2 \\
\hline Autumn & 24 & 2 & 26 & 4.6 & 0.6 & 3.0 & 10.6 & 1.5 & 7.3 & 5.0 & 0.8 & 3.6 \\
\hline Total & 76 & 22 & 98 & 5.1 & 1.7 & 3.5 & 10.6 & 5.8 & 8.9 & 5.9 & 3.0 & 4.8 \\
\hline
\end{tabular}

It can be seen that many more deaths occurred in both species in the first half of the study period; this point will be returned to later. A seasonal pattern in mortalities is also evident but differs slightly between the two halves of the study and between the two species. Mouse deaths were very low in the summer months and they increased to a peak in the winter (1975-1977) or the spring (1978-1980). The number of deaths in voles was lowest in the summer, increased through autumn and winter to reach high levels in the spring. The seasonal incidence in trap mortality is apparent in each of the four measures 
of trap deaths presented in Table 1 suggesting that the number of deaths is not directly related to the number of trap-nights, number of individuals captured or number of captures. It is of some concern that a proportionally high number of individuals died in traps at certain times during the study and especially disturbing was the overall $16 \%$ figures for voles in the spring period.

Table 2 shows that the number of deaths in mice increased gradually over the four nights within the trap period; four times as many indivi-

\section{Table 2}

Number of deaths according to night of trapping. Expected number of deaths on each night (in brackets) calculated from the frequency distribution of all individuals captured each night.

\begin{tabular}{|c|c|c|c|c|c|c|c|c|c|c|c|c|c|}
\hline \multirow[t]{2}{*}{ Species } & \multicolumn{3}{|c|}{1} & \multicolumn{3}{|c|}{2} & \multicolumn{3}{|c|}{3} & \multicolumn{3}{|c|}{4} & \multirow[t]{2}{*}{ Chi-square } \\
\hline & & $\mathrm{n}$ & $\mathrm{n} / \mathrm{t}$ & & $\mathrm{n}$ & $n / t$ & & $n$ & $n / t$ & & $\mathrm{n}$ & $n / t$ & \\
\hline Mice & 9 & (19) & 0.16 & 15 & (19.5) & 0.27 & 25 & (21.5) & 0.46 & 31 & (20) & 0.69 & $12.9214^{* *}$ \\
\hline Voles & 18 & (24) & 0.33 & 18 & (26) & 0.33 & 18 & $(25)$ & 0.33 & 44 & (23) & 0.98 & $25.0955^{* *}$ \\
\hline
\end{tabular}

** Chi-square, $p<0.01$

Table 3

Number of deaths according to sex and breeding condition (percentage of those captured in brackets). Expected values calculated from the frequency distributions of sex and breeding condition of animals captured. $b r=b r e e d i n g$, non-br=nonbreeding.

\begin{tabular}{lllllll}
\hline & Male-br. & $\begin{array}{c}\text { Male } \\
\text { non-br. }\end{array}$ & Female br. & $\begin{array}{c}\text { Female } \\
\text { non -br. }\end{array}$ & Juvenile & Total \\
\hline Observed & $16(3.8)$ & $22^{*}(9.5)$ & $\begin{array}{c}\text { Wood mice } \\
16(9.3)\end{array}$ & $8^{*}(2.6)$ & $18(6.5)$ & $80(5.7)$ \\
Expected & 24 & 13 & $\begin{array}{c}10 \\
\text { Bank voles }\end{array}$ & 17.5 & 15.5 & \\
Observed & $14^{* *}(4.3)$ & $22(10.8)$ & $23^{* *}(22.5)$ & $12^{*}(4.9)$ & $27^{*}(14.1)$ & $98(9.2)$ \\
Expected & 30 & 19 & 9 & 22.5 & 17.5 & \\
\hline
\end{tabular}

*Chi-square, $p<0.05$, ** Chi-square, $p<0.01$.

duals died on the fourth night of trapping compared with the first. No differences between the number of voles dying on nights 1,2 or 3 were found but there was a significant increase in the number of vole deaths on the fourth night. Perrin (1975) reported an increase in the number of vole deaths at the end of four-night trapping periods, but as he states, the reason for this is unclear. Montgomery (1981) also observed an increase in the number of vole deaths on nights 3 and 4 , but the increase was not significant.

Table 3 presents the number of deaths according to sex and breeding condition. In mice, non-breeding males and breeding females appear to have been the most vulnerable groups, whereas in voles it was 
breeding females and, as Montgomery (1981) found, juveniles. Of the 38 voles which died during the spring period 10 were breeding males, 6 breeding females, 11 non-breeding females and 10 juveniles. Nine of the 13 mice which died during the spring were breeding males.

Fern; (1978) found that a larger number of field voles which were unmarked at the beginning of a trap period died than those which were marked. This was also found in the present study for bank voles (Table 4) but the reverse situation was found in mice. Further, deaths in voles most frequently occurred amongst those animals which were captured for the first time within a trap period (Table 4) and these

Table 4

Deaths according to capture history. The marked and unmarked categories refer to the mark status of the animals at the beginning of a trap period. Expected numbers (in brackets) calculated from the appropriate frequency aistribution for all captures.

\begin{tabular}{lllllcr}
\hline \multirow{2}{*}{ Species } & \multirow{2}{*}{ Marked } & \multirow{2}{*}{ Unmarked } & \multicolumn{4}{c}{ No. of previous captures } \\
\cline { 5 - 7 } & & & 0 & \multicolumn{1}{c}{1} & \multicolumn{1}{c}{2} & 3 \\
\hline Mice & $53(46)$ & $27(34)$ & $24(26)$ & $20(20.5)$ & $22(18)$ & $14(15.5)$ \\
Voles & $34^{* *}(56.5)$ & $64^{* *}(41.5)$ & $59^{*}(44.5)$ & $12^{*}(24.5)$ & $18(19)$ & $9(10)$ \\
\hline
\end{tabular}

*Chi-square, $p<0.05$, ${ }^{*}$ Chi-square, $p<0.01$.

Table 5

Relative frequency of trap deaths expressed as percentages, according to: (a) minimum temperature; (b) rainfall, and (c) relative humidity. Note: no relative humidities of less than $50 \%$ were recorded on days when animals died in traps.

\begin{tabular}{|c|c|c|c|c|c|c|c|c|}
\hline \multicolumn{3}{|c|}{ (a) } & \multicolumn{3}{|c|}{ (b) } & \multicolumn{3}{|c|}{ (c) } \\
\hline Temp. $\left({ }^{\circ} \mathrm{C}\right)$ & Mice & Voles & Rain (mm) & Mice & Voles & Rel. Hum. & Mice & Voles \\
\hline$>10$ & 3 & 5 & 0 & 30 & 55 & $>95$ & 40 & 25 \\
\hline $5.5-10$ & 23 & 37 & $0.1-2$ & 25 & 13 & $90-94$ & 26 & 14 \\
\hline $2.5-5$ & 21 & 15 & $2.1-5$ & 31 & 11 & $85-89$ & 16 & 12 \\
\hline $0.5-2$ & 30 & 15 & $5.1-10$ & 13 & 19 & $75-84$ & 8 & 23 \\
\hline$<0.5$ & 24 & 28 & $>10$ & 1 & 1 & $50-75$ & 10 & 27 \\
\hline
\end{tabular}

findings quite closely agree with those of Perrin (1975) and Montgomery (1981) for bank voles. In comparison, mice showed no significant relationship between the number of previous captures within a trap period and the death of individual animals.

Table 5 examines the number of trap deaths in relation to minimum forest floor temperature, rainfall and relative humidity. Few deaths occurred at temperatures above $10^{\circ} \mathrm{C}$ but there is no clear association between number of deaths and depression of temperature below $10^{\circ} \mathrm{C}$. These data do not agree with Perrin (1975), therefore, who found that deaths progressively increased at extremes of temp. Montgomery (1981) 
indicated that deaths in bank voles were linked with low temperatures rather than rainfall and Perrin (1975) showed that rainfall has some effect on trap mortality but not markedly so. Table 5 shows that more than half the vole deaths occurred when there was no rain at Alice Holt but, in contrast $70 \%$ of the mice died when there was some rain. These inverse trends are also reflected in the relative humidity figures. $66 \%$ of the mice died at fairly high relative humidities $(>90 \%)$; the comparable figure for voles was only $39 \%$ and $50 \%$ of voles died at relative humidities of less than $75 \%$. It should be pointed out that in December 1977 seven mice died on one night which had $0.6 \mathrm{~mm}$ of rain and minimum ground temperature of $-0.5^{\circ} \mathrm{C}$; densities were also high at this time (see below).

Table 6 shows that there is no clear association between number of deaths and population density although it is noticeable, especially in

Table 6

Number of deaths during a trap period, if greater than 2, according to population density.

\begin{tabular}{|c|c|c|c|c|c|}
\hline \multicolumn{3}{|c|}{ Mice } & \multicolumn{3}{|c|}{ Voles } \\
\hline Date & $\begin{array}{l}\text { No. } \\
\text { deaths }\end{array}$ & $\begin{array}{l}\text { Density } \\
\text { (no/ha) }\end{array}$ & Date & $\begin{array}{c}\text { No. } \\
\text { deaths }\end{array}$ & $\begin{array}{l}\text { Density } \\
\text { (no/ha) }\end{array}$ \\
\hline Oct '75 & 3 & 34 & Sept 75 & 4 & 27 \\
\hline Nov '75 & 7 & 21 & Jan 76 & 3 & 14 \\
\hline Oct '76 & 4 & 27 & Mar '76 & 3 & 10 \\
\hline Nov' 76 & 10 & 57 & Aug '76 & 5 & 18 \\
\hline Dec '76 & 10 & 100 & Nov '76 & 6 & 20 \\
\hline Jan ' 77 & 13 & 109 & Dec '76 & 3 & 32 \\
\hline April 77 & 3 & 81 & Jan ' 77 & 3 & 46 \\
\hline Dec '77 & 10 & 45 & Mar '77 & 10 & 44 \\
\hline Mar '79 & 5 & 38 & May '77 & 7 & 49 \\
\hline & & & May 77 & 6 & 47 \\
\hline & & & Oct 77 & 3 & 64 \\
\hline & & & Dec ' 77 & 4 & 57 \\
\hline & & & Mar '78 & 3 & 20 \\
\hline & & & Jan' '79 & 3 & 23 \\
\hline & & & Mar 79 & 4 & 17 \\
\hline & & & May '79 & 4 & 19 \\
\hline
\end{tabular}

mice, that more than two deaths in a trap period occurred when the populations were at moderate to high densities. Significantly, 43 of the 80 mouse deaths occurred in just four trap periods, and three of these periods; November 1976 to January 1977, were connected with a build-up to very high densities over the winter of $1976-7$ which in turn was associated with a very good tree seed crop in the autumn of 1976. Full details of the dynamics of the populations over the study period are given by Gurnell (1981). It should also be mentioned that November 1976 was cool and dry, whereas December 1976 and January 1977 were cold and wet. 
Voles also showed an increase in density during the autumn of 1976 and numbers stayed high throughout 1977 before falling again early in 1978. Numbers of deaths in voles were particularly high between March and May 1977. However, weather doesn't seem to have influenced trap mortalities over this time, for example, March 1977 was warm and dry.

As discussed above trap deaths in both species were much lower in the second half of the study period $(1978-1980)$ that the first half (1975-1977). This in part must be linked with the high densities of animals in the first part of the study particularly from the autumn of 1976 through to the end of 1977. Tree seed crops were poor in the autumns of 1977, 1978 and 1979 and so numbers never reached such high densities as in 1976 and 1977.

\section{DISCUSSION}

Differences and similarities in the pattern of trap deaths between wood mice and bank voles can be seen from the present study. In general, fewer mice than voles died in traps, more mice died in wet or damp weather conditions and there was a significant peak in vole deaths in the spring which was not always seen in mice. More deaths occurred in both species at high densities, hardly any animals died during the summer months, and trapping for three rather than four nights would be have considerably reduced mortalities in both species. From all the evidence which has been put forward there appears to be two groups of factors which are important in influencing the numbers of trap deaths: these are extrinsic factors associated with temperature and moisture, and intrinsic factors related to the physiological condition of the animals.

Corke (1967) found that damp bedding was associated with trap deaths in wood mice and bank voles and intuitively it has always been believed that cold, wet weather conditions can result in trap mortalities. Animals with damp fur and in damp bedding would be unable to thermoregulate efficient1y and low, or even high (Perrin, 1975), temperatures would take their toll. It has been shown that very few animals die in traps during the summer months but a closer agreement between number of deaths and cold, wet weather at other times may be obscured in the present study by the precautions taken to minimise trap mortalities by stopping the trap session or deferring the start of a trap session in unfavourable weather conditions. Nevertheless, $70 \%$ of the mice which died in traps did so when some rain had fallen during the previous 24 hours, and most deaths occurred when there were high relative humidities. This was not found to be the case for voles, but dead voles 
were usually associated with damp bedding. This is a result of the fact that voles have a tendency to urinate a great deal after capture and generally foul the trap; mice show no such tendency (Bergstedt, 1965; Perrin, 1975). In addition, damp conditions could persist in a trap from one night to the next and partly be responsible for the observation that more animals died on the fourth night of trapping. Ferns (1978) has also pointed out the possible importance of condensation within the trap, dew and surface water in his grassland studies.

Various types of cover for traps or trapping procedure have been suggested to minimise the effects of weather on trap occupants (e.g. Dodge \& Cambell, 1965; Iverson \& Turner, 1969; Miller \& Getz, 1968; Perrin, 1975; Shaw \& Miller, 1967). At the present time simple wooden shelters are being tested in the study area to see whether they reduce trap mortalities. However, the results so far suggest that they have little effect in reducing deaths particularly where bank voles are concerned.

Physiological stress within the animals resulting from, for example aggression and high activity during the spring, dispersal or high densities of animals may contribute towards trap mortalities (Andrzejewski \& Wrocławek, 1961; Archer, 1970; Chitty, 1959; Chitty \& Phipps, 1966; Platt, 1968), and especially if exacerbated by stress resulting from confinement in the trap. Noticeably, breeding female voles and mice were more susceptible to trap death than non-breeding females, but the reverse was true for males. More important was the spring peak in trap deaths in voles and, to a lesser extent, mice during the second part of the study. This may result from some animals within the population coming into breeding condition and the associated levels of aggression and activity (Ferns, 1978; Gurnell, 1978). A corollary to this is that stressed animals may be more likely to urinate on their bedding than unstressed animals. Furthermore, Gurnell (unpubl.) has shown that mice and voles are very active in traps after they are captured and this continuous activity can last for several hours. This leaves little time for feeding on the food within the trap (Ferns, 1978) and exhaustion may influence trap mortalities. Routtenberg and Kuzenof (1967) have shown that laboratory rats on a restricted feeding schedule can effectively starve themselves by excessive running in an activity wheel High activity in the trap after capture was not associated with animal density, weather or time of the year.

It has been mentioned that animal densities were high from the autumn of 1976 through to the end of 1977 (see Gurnell, 1981). During this time there were 14 trap periods but during only 6 periods in mice and 8 periods in voles did more than two animals die in the traps 
Therefore, although high numbers of trap deaths occurred at high densities, high densities did not necessarily result in a high number of trap deaths. Montgomery (1981) also failed to detect any relationship between density and trap mortality in wood mice and bank voles. The turnover of individuals was also high, particularly during the increase and peak phases in the autumn of 1976 and early in 1977 (Gurnell, 1981) and, therefore, trap deaths tended to occur at times of high mortality or dispersal (see Ferns, 1978; Montgomery 1981; Platt, 1968), within the period of high population density.

In conclusion, the present findings are in general agreement with Ferns (1978) and Perrin (1975) that moisture within the trap, associated with low temperatures, is a major contributing factor towards trap mortalities. Stress resulting from confinement and the start of the breeding season can also be important, but animal densities and numbers of trap deaths are not strongly correlated. In accordance with the findings of Montgomery (1981), bank voles appear to be more vulnerable to dying in traps than mice, and juvenile voles and voles captured for the first time seem to be especially at risk. Unfortunately, the present study provides no evidence for or against the suggestion of Montgomery (1981) that A. flavicollis individuals which are susceptible to dying in traps are selectively removed leaving a greater proportion of trap death resistant phenotypes in the population.

Acknowledgments: I should like to thank Dr. A. M. Gurnell for her comments on the manuscript and the Forestry Commission for permission to work at Alice Holt Forest.

\section{REFERENCES}

1. Andrzejewski R. \& Wrocławek H., 1961: Mortality of small rodents in traps as an indication of the diminished resistance of the migrating part of a population. Bull. Acad. Pol., Cl. II, Ser. Sci. biol., 2: 491-492.

2. Archer J., 1970: Effects of aggressive behaviour on the adrenal cortex in male laboratory mice. J. Mammal., 51: 327-332.

3. Bergstedt B., 1965: Distribution, reproduction, growth and dynamics of the rodent species Clethrionomys glareolus (Schreber), Apodemus flavicollis (Melchior) and Apodemus sylvaticus (Linné) in southern Sweden. Oikos, 16: $132-160$.

4. Chitty D., 1959: A note on shock disease. Ecology, 40: 728-731.

5. Chitty D. \& Phipps E., 1966: Seasonal changes in survival in mixed populations of two species of vole. J. Anim. Ecol., 35: 313-331.

6. Corke D., 1967: The deaths of small mammals in live traps. J. Zool., Lond., 153: 552 .

7. Dodge W. E. \& Cambell D. L., 1965: Two techniques to reduce capture mortality. J. Mammal., 46: 707.

8. Ferns P. N., 1978: Trap mortality in Microtus agrestis (L.). Z. Säugetierkunde, 43: 92-101. 
9. Gurnell J., 1978: Seasonal changes in numbers and male behavioural interaction in a population of wood mice, Apodemus sylvaticus. J. Anim. Ecol., 47: $741-755$.

10. Gurnell J., 1981: Woodland rodents and tree seed supplies. [In: "Worldwide Furbearer Conference Proceedings," J. A. Chapman and D. Pursley eds.]. R. R. Donnelly \& Sons Co., Falls Chard, Virginia, U.S.A.

11. Gurnell J., 1982: Trap response in woodland rodents. Acta theriol., 27, 10: 123-137.

12. Iverson S. L. \& Turner B. N. 1969: Under-snow shelter for small-mammal trapping J. Wildl. Manage., 33: 722-723.

13. Miller D. H. \& Getz L. L. 1968: A method to reduce winter trap mortality. J. Mammal., 49: 147.

14. Mongomery W. I., 1981: Mortality of small rodents captured in live traps. Acta theriol., 25: 277-284.

15. Perrin M. R., 1975: Trap deaths. Acta theriol., 20: 167-174.

16. Platt A. P., 1968: Differential trap mortality as a measure of stress during times of population increase and decrease. J. Mammal., 49: 331-335.

17. Routtenberg A. \& Kuzenof A. W., 1967: Self starvation of rats living in activity wheels on a restricted feeding schedule. Physiol. Psychol., 64: 414 421.

18. Shaw M. W. \& Milner C., 1967: The use of insulating covers for Longworth traps. J. Zool., Lond., 153: 546-551.

Accepted, March 15, 1982.

John GURNELL

\section{SMIERTELNOŚC GRYZONI LESNNYH W PUŁAPKACH}

\section{Streszczenie}

Badano wpływ różnych czynników na śmiertelność nornicy i myszy zaroślowej w pułapkach żywołownych. Odłowy prowadzono 5 lat, w różnych sezonach roku, w dąbrowach południowej Anglii. Pułapki użyte do doświadczeń wyposażone były $\mathrm{w}$ gniazdo $\mathrm{z}$ siana $\mathrm{i}$ owies, będący przynętą i pokarmem. W czasie trwania eksperymentu notowano dobowe warunki pogodowe, temperaturę i wilgotność. Złowione osobniki znakowano przez obcięcie palca, ważono, określano płeć i stan aktywności płciowej i wypuszczano. Notowano również liczbę i gatunek padłych zwierząt (Tabela 1 i 2) oraz fakt czy były one już znakowane, czy jeszcze nie (Tabela 4).

Okazało się, że wilgotność w pułapkach i towarzysząca jej niska temperatura są najważniejszymi czynnikami wywołującymi śmiertelność w pułapkach (Tabela 5 i 6). Duży wpływ na nią mają również: stres wywołany złowieniem i udział w sezonie rozrodczym (Tabela 3 ). 